\title{
Lounge Designs for the Budapest Office of a Multinational Company
} Ágnes Borsos ${ }^{1 *}$, Thimea Hendrix ${ }^{2}$, Dalma Lovig ${ }^{2}$, Nesma Sadoud $^{2}$, Erzsébet Szeréna Zoltán $^{3}$, Gabriella Medvegy $^{1}$,
Erzsébet Bachmann

${ }^{1}$ Department of Interior, Applied and Creative Design, Faculty of Engineering and Information Technology University of Pécs, Boszorkány út 2., H-7624 Pécs, Hungary

${ }^{2}$ Marcel Breuer Doctoral School, Faculty of Engineering and Information Technology University of Pécs, Boszorkány út 2., H7624 Pécs, Hungary

${ }^{3}$ Department of Architecture and Urban Planning, Faculty of Engineering and Information Technology University of Pécs, Boszorkány út 2., H-7624 Pécs, Hungary

${ }^{4}$ Department of Visual Studies, Faculty of Engineering and Information Technology University of Pécs, Boszorkány út 2., H7624 Pécs, Hungary

Corresponding Author Email: agnesborsos@mik.pte.hu

https://doi.org/10.18280/ijdne.150401

Received: 15 May 2020

Accepted: 20 June 2020

\section{Keywords:}

lounges, office-space architecture, open-plan design, reducing office stress, work health, workplace recreation areas

\begin{abstract}
The research examines the function, design principles, and physical features of the lounges of open-plan offices and presents them through the lounge designs of the Budapest office building of a multinational company. The design developed from the questionnaire, which was evaluated by descriptive statistical analysis and used in the concept development process. The design sought answers to the problems arising from the open-plan office design, without any changes in the workspace though. The predesign study was not limited to the lounge spaces. The project also required an analysis of the overall office design to make out the deficiencies and needs. The new lounge design provides better working conditions even with the workspaces untouched. The design aims to create dedicated spaces where activities that reduce work performance can be relocated from the office space, thus reducing the load on the space. The research aims to develop a system of criteria and planning methodology - based on the results of a workspace questionnaire - that contributes to increasing employee comfort and work efficiency. The results of the questionnaire revealed that those working in the open-plan offices were primarily disturbed by the noisy work environment, congestion and lack of private space - these factors determined the function selection and design of the lounges.
\end{abstract}

\section{INTRODUCTION}

The research aims to design an informal office group of spaces that enhances individual comfort and reduces the health risks of working.

The questionnaires completed by the employees and the results of the comfort measurements helped us to determine the problems arising from the location and the spatial layout of the building, and we attempted to provide an architectural solution to them through the conversion of the existing lounges.

\subsection{Research review}

The concept of open-plan offices has been addressed in several studies in the past and is still addressed today [1-4]. According to Candido's research, only 4 scientific articles on the Scopus platform examined the topic in 1999 - counting articles where the term 'open-plan office' was included in the title, abstract or keywords of the research - in 2018 there were fifteen times as many, 60 studies on the topic [1]. In recent years, healthy buildings, designed to improve indoor environmental quality, have become increasingly common. According to Kim's research, the basic requirements for office buildings have become the existence of creative and collaborative spaces, the integration of modern technologies, and the provision of adequate indoor air quality, lighting systems and acoustics [2]. In Candido's research workspaces were examined in terms of productivity, comfort and health, and based on the answers of the questionnaire, spatial comfort, indoor air quality, noise distraction and privacy, visual comfort, personal control, connection to the outdoor environment and building image \& maintenance were the determinants [1]. Delle Macchie's research examined the effect of environmental factors on concentration. The survey shows that noisy work environments reduce concentration by $35 \%$, inadequate lighting by $5 \%$ and inadequate microclimate by $10 \%$ [3]. When performing intellectual work, it takes $15-20$ minutes to reach the appropriate concentration level; this is the amount of time it takes to reach the appropriate level of concentration again after encountering confounding factors e.g., after a conversation or phone ring. According to research, above all other noise pollution, irrelevant speech noise (ISN) is the most distracting for workers. The results of Di Blasio's questionnaires show that ISN distracts $66 \%$ of open-plan office workers out of concentration, causing mental problems for $6 \%$ of them - e.g. stress - in $9 \%$ develops a negative emotional or social state - e.g., decreased motivation, anger, or other negative emotions - $9 \%$ also experience physical 
symptoms in case of persistent ISN - e.g., fatigue, exhaustion, headache [4]. This research examines the ways of mitigating the mentioned problems in the case when the transformation of the workspace is not an option, and it is only possible to change one space - in this case, the lounges.

\subsection{Stress at work and health}

The nature of the work and the office design have a significant impact on the physical and mental health of the employees $[5,6]$. In the long run, sedentary work - due to static loading of the musculoskeletal system - takes a toll on the skeletal and muscular system, which mainly affects the upper body due to the sitting position [7]. Damage can be prevented by providing well-designed ergonomic workstations, inserting breaks and doing exercise during breaks. Developing a lounge suitable for working out and stretching contributes to maintaining the health of workers, which in the long run will result in positive change at both individual and organizational levels [8].

The consequences of the modern accelerated way of life are also manifested in the workplace [9, 10]. Increasing expectations, tight work schedules and tight deadlines all add to the tension in the workplace. According to a Hungarian survey conducted in $2019,55 \%$ of the responders have no break provided at work, another $13 \%$ have breaks but do not respect them, $13 \%$ of workers had such a disease or long-term health damage caused by high levels of work-related stress. In offices where employees have rest periods that are respected, the stress rate is significantly lower [11]. In a 2015 European Working Conditions Survey, 25\% of respondents in Hungary said that their work is almost always tense, while $28 \%$ face strict, tight deadlines [12]. The factors - examined previously, - increase the level of work-related stress $[13,14]$ and reduce work efficiency; however, well-designed recreational spaces can reduce stress levels.

\subsection{The advantages and drawbacks of open-plan offices}

The first open-plan offices emerged in the United States in the early 20th century; later, the proliferation of single-unit office systems made this kind of layout less prevalent. As a result of the digital development in the 1990s, in parallel with the growing demand for teamwork, open-plan office systems became widespread again.

The advantages of open-plan offices lie in their flexibility, the possibility of teamwork and easier communication $[15,16]$, and the lack of a hierarchical system. Research shows that noisy work environments [17-21], congestion, and lack of private space [22] hinders workers in the open-plan office from working efficiently; as opposed to small offices, it is more challenging to provide the ideal comfort for everyone in terms of lighting, temperature, ventilation [23, 24]. Problems arising from the design of open-plan offices can be offset with properly selected additional rooms - e.g., focus rooms, lounges, or meeting rooms [25]. By choosing the functions for the lounges and organizing their spaces, we aimed to respond to the problems mentioned above and, where possible, to provide an architectural response to them.

\subsection{The impact of digital evolution and the emergence of new generations on office design}

The evolution of digital technologies and the needs of new generations have significantly changed the expectations regarding office space: spaces suitable for teamwork and collaboration have gained key importance. Nowadays, up to 4 generations, i.e., baby boomers, $\mathrm{X}$-, $\mathrm{Y}$ - and Z-generations can work in an office at the same time [26, 27].

A fundamental difference between the generations is their relationship to digital technology: while baby boomers began using the Internet in their $30 \mathrm{~s}$ or $40 \mathrm{~s}$, members of the Zgeneration were born into the digital world [28, 29]. The difference between age groups is also reflected in the different motivations and preferences of its members [30].

While members of Generation Y prefer open, unstructured workspaces offering choice and flexibility, members of Generation $\mathrm{X}$ find traditional workplaces comfortable, but integrate the new workspace principles well [31].

\section{DESIGN METHOD}

At the client's request, the design originates not only from the results of the questionnaire but also from the field research. Typical aspects of modern office design were taken into consideration: people- and health-focused design and the impact of generations on office space. The study of workplace stress and health, just as the analysis of the needs of different generations influenced the functions and design of the spaces significantly. The research included an examination of the advantages and disadvantages of open-plan offices - the aim of which is to support the results of the questionnaire with further scientific results.

In the summary of the research, the typical office design tendencies of today and the peculiarities arising from the design of open-plan office spaces together defined the concept of the planned spaces.

The choice of functions of the established recreational and sports lounge was justified by the need to ensure a healthy work environment and the possibility of relieving stress at work. The design of the e-sport lounge is primarily based on the needs of generations $\mathrm{Y}$ and $\mathrm{Z}$, who have a different relationship with the digital world than the previous generations.

The problems and peculiarities of the open-plan offices revealed during the research match the results of the questionnaire, which was evaluated by descriptive statistical analysis and used in the conception; they confirm that the most significant disadvantages of spatial design are the noisy work environment and the lack of private space. Research has confirmed that work efficiency, workplace comfort, and health are influenced by two factors that have been addressed in several previous studies [1-4]; however, their connection to community and recreational spaces has no comprehensive studies. One peculiarity of the planning was that office-level problems had to be solved only by redesigning the given spaces: relocating noise inducing and distracting activities, along with designing adequate visual and acoustic separation, became extremely important.

The architectural concept was based on descriptive statistical analysis that was based on the results of the questionnaires, the results of the research work, and a design method with a focus on health preservation. Based on the results, a system of design criteria was developed, the elements of which are: relocation of disturbing functions from the workspace to reduce the noise of the office space; creation of acoustically and visually private spaces; selection of functions 
that support healthy work environment; the possibility of reducing stress at work in the premises; creation of hybrid spaces, creation of active and reflexive zones as alternative workspaces; the opportunity to improve / create workplace relationships; aesthetic - but not self-serving - use of space and materials based on functional needs.

The tool for integrating the criteria into the design is the choice of colors and materials, space design and shaping. The formation of spaces and space elements, as well as the use of materials, were primarily determined by acoustic considerations; the choice of color and material was justified by the need to differentiate from the workplace (to increase the recreational effect; based on Stephen Kaplan's ART theory) and their defining effect on the relationship between human and space. Employee suggestions, generational preferences, and the needs for healthy work opportunities were decisive in determining the functions of the spaces.

\section{RESULTS}

\subsection{System of design criteria}

A dual study preceded the design analysis of the results of the questionnaires and research of the relevant literature and scientific articles; the design method was based on the criteria developed on the basis of the above. One of the foundations of the design is a descriptive statistical analysis based on the results of the questionnaire. The client needed the redesign of the existing lounges, before starting with the design of the given spaces, the entire office space needed to be examined. The feedback on the office space given in the questionnaires determined the design: it revealed the needs of the employees, the shortcomings of the space, and the necessary changes. The concept of the new lounges compensates for the shortcomings of the working spaces (e.g., noisy work environment, lack of private space) by relocating some functions and creating extra functions. In examining the relevant literature and scientific articles, we searched for and integrated the factors that determine today's office design methods into our design method.

\subsection{Phonebooth lounge}

When designing this lounge, our goal was to design a multifunctional space where phone calls can be made without disturbing the environment, as well as an area where tasks requiring high concentration can be performed. Besides due to the design of the lounge, it is suitable for small group meetings and short individual retreats and relaxation. An essential aspect of the design was to design open, semi-enclosed, and entirely separable cabins to suit user needs. The furniture of the lounge was selected according to ergonomic and comfort considerations. Ergonomic suggestions have been taken into account in the design of the custom-made seating furniture. Due to the function of the room, fixed furniture was installed in the booths and mobile furniture in the central open space thus ensuring the possibility of the multifunctional character of the space. The mobile elements, we chose have curved shape, thus breaking the strict angular design of the space (Figure 1, Figure 2).
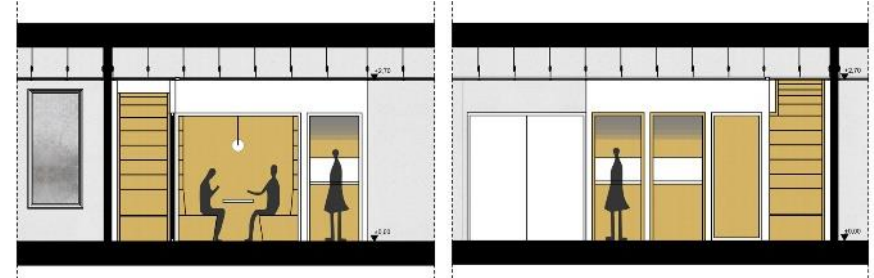

Figure 1. The conceptual design of the phonebooth lounge

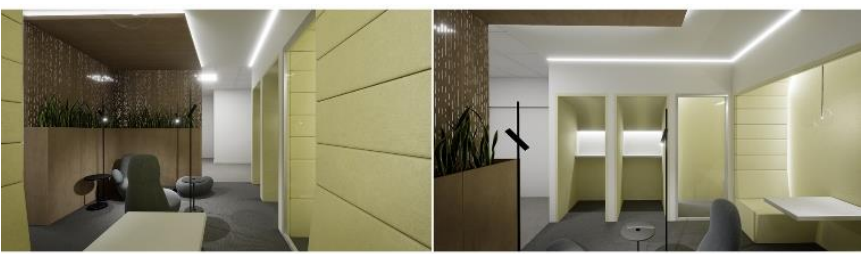

Figure 2. Visualization of the phonebooth lounge

\subsection{E-sport and cinema lounge}

The lounge consists of two separate parts that perform different functions: the small booths provide space for individual tasks that cannot be performed at the desk, while the larger cohesive space is suitable for arranging group events. When designing the furnishings of the room, customization was a priority: except for the pre-installed curved display and the large sofa, the furnishing of the area is made up of easily movable mobile elements. Unlike formal office spaces, the design of informal areas is of less fixed character; a critical consideration in the design was to create a lounge that would be suitable for distracting the employees during breaks and reducing stress at work. When selecting the materials used in the room, we consciously chose materials less typical for office spaces: softer-touch upholstery and sponge surfaces as well as natural wood wall coverings (Figure 3).

During the design of the lounge, it was essential to provide visitors with features offering exceptional experiences through the achievements of modern digital technology: the large, curved display with game consoles provides an opportunity to relax during breaks and after-hours joint programs (Figure 4).

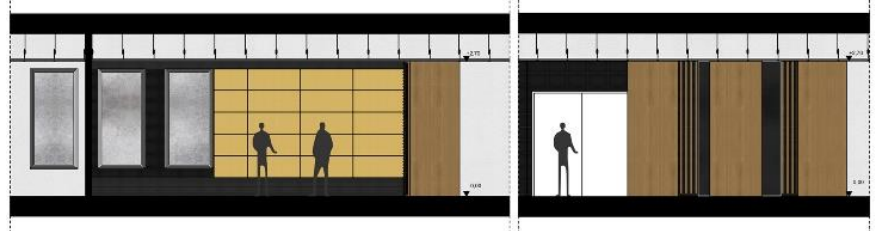

Figure 3. The conceptual design of the e-sport lounge
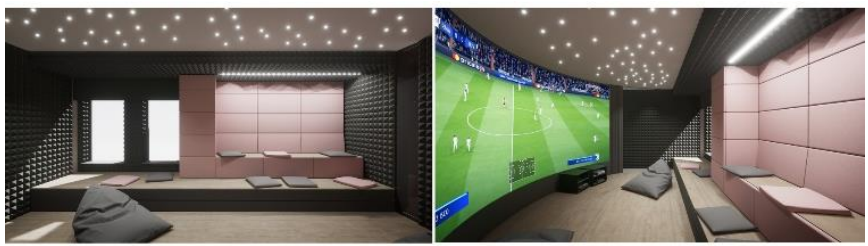

Figure 4. Visualization of the e-sport lounge 


\subsection{Sports and relaxation lounge}

When creating the design of the sports lounge, our goal was to establish a space that, through its function and design, is suitable for reducing the level of stress at work and offsetting the detrimental effects of working long hours in front of a display. Sports equipment in the lounge allows for versatile use of the room. The elements of the system that can also be used as a circular track include a balancing cylinder, a stretching wall, a cliff-hanger ladder, a pool of balls, a trampoline and a basketball backboard. Boxing bags, pullrings, and TRX straps were attached to the off-orbit stretch of the climbing system; while the space left empty is suitable for meditation and doing yoga exercises.

The open-plan design of the lounge supports the spontaneous creation of group programs. We placed a scoreboard on the outer boundary wall of the room, intending to generate a healthy competition among the employees of the office. Competition can motivate to use the gym and do sports exercises during breaks (Figure 5, Figure 6).

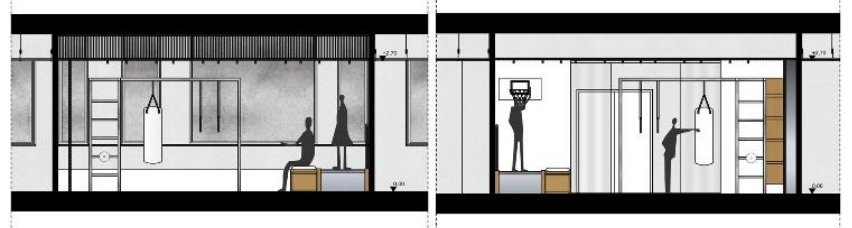

Figure 5. The conceptual design of the sports lounge

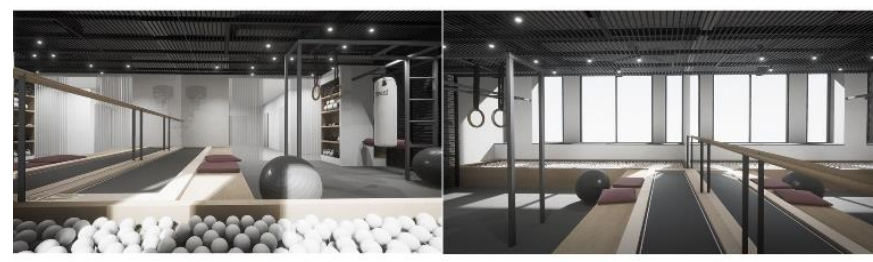

Figure 6. Visualization of the sports lounge

\section{DISCUSSION}

\subsection{Location}

We performed our study at the regional headquarters of a multinational company, built in 2018. The seven-story office building includes approximately 17,300 square metres of office space; the wings of the building enclose 5,500 square meters of multifunctional gardens. The lounges under study are located on the 1st and 2nd floors of the building; their immediately adjacent spaces include open-plan and small offices and meeting rooms.

\subsection{Spaces to be transformed}

There are two lounges on each floor of the office building, which are in the same position on each level. The phonebooth lounge is located on the 2nd floor of the office building; the small room, only 17.67 square meters - enclosure size: 4.11 meters $\times 4.30$ meters - has a windowless design. The space is bordered on two sides with corridors, while the immediate rooms include an open-plan office and a meeting room. The esport and sports lounges are located on the 1 st floor of the building, their floor area is almost the same: the former is of
33.94 square metres, the latter is of 34.63 square metres - their enclosing dimensions are 7.16 meters $\mathrm{x} 4.47$ meters; and 5.80 x 5.97 meters respectively. The e-sport lounge windows are overlooking the garden, facing northwest, while the sports lounge windows face northeast and overlooking the street. The ceilings of the lounges are uniformly of 2.70 meters.

\subsection{The role of lounges}

Lounges are informal office spaces that are hybrid by character: they can be active or reflexive zones depending on their function. Active spaces support collaborative work, communication, and group programs [32]; while reflexive spaces are suitable for individual occupations - e.g., performing demanding tasks, making phone calls - and isolating. The role of informal spaces in office design today is increasingly important, mainly due to the shift in the nature of work as well as the needs of new generations. Informal spaces do not replace, merely complement formal spaces [33, 34]; finding the right balance between the two is essential for efficient, functional office design [25].

\subsection{Private spaces}

Creating private zones can enhance the sense of security and improve the mood of employees. The primary physiological need of workers is having privacy, which has three defining elements: visual, verbal, and physical personal space. Securing privacy at a workstation reduces the problems arising from open-plan office design, provides more efficient work, and offers a more stress-free work environment. Using informal spaces - e.g., lounges - allows employees to work or relax in their private space, even when they are away from their workstation. In the lounges, visual and verbal personal space can be provided by means of demarcations, subdivisions, and tiles, while the design of the appropriate raster guarantees the undisturbed physical space of the employees.

\subsection{Impact of well-designed recreational areas}

Providing a healthy work environment and well-designed recreational areas has several benefits at both individual and organizational levels: reduced stress levels positively affects absenteeism and illnesses, increases mental and physical performance, and enhance creativity. Better work ethic improves work atmosphere and conflict management within the team. The benefits at organizational level include the decrease of absences due to sick leaves as well as fluctuations, while the corporate image, the attractiveness of the workplace and productivity are improved [35].

\subsection{Functions of recreational areas}

The answers provided in the employee questionnaire and the suggestions made by the employees for the functions helped us to define the functions of the spaces; they revealed that despite working with computers, there is a significant need for digital recreation during breaks. A common trait of Generations $\mathrm{Y}$ and $\mathrm{Z}$ is that, in addition to their work, the platform for their recreation and social relationships is also the digital space; this justified the creation of a seemingly somewhat controversial recreational area, the e-sport longue.

Due to the open-plan office design, certain functions can be distracting for those working in the room. Thus, we also 
proposed to move them to another space. By relocating telephone calls and small group - formal and informal meetings to lounges, the underlying noise load of workspaces can be significantly reduced.

The purpose of creating a sports lounge is to support the healthcare at work; during breaks employees can play sports, relax and do stretching exercises in the longue concerned. Depending on their function, the recreational areas can provide privacy, a haven for retreat and relaxation - i.e., the phonebooth lounge - help workplace networking and communication - i.e., the e-sport lounge - and provide an alternative to stress relief and healthy relaxation - i.e., the sports lounge (Figure 7).

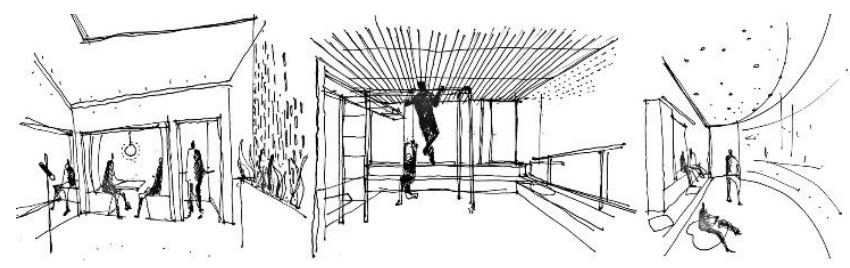

Figure 7. Conceptual sketches of the designed lounges

\subsection{Concept}

ART, i.e., Attention restoration theory, which also plays a vital role in the concept of lounges, was developed in 1989 by Rachel and Stephen Kaplan [36]. In ART, the physical properties of retreat rooms that help the worker in mental refreshment, regeneration, and stress processing have been researched. Based on the distinction between intentional and involuntary attention, the researchers examined the consequences of fatigue of controlled attention and the characteristics of situations and environmental stimuli that promote regeneration. As a result of fatigue of attention, workers' mental capacity, planning ability and sensitivity to social stimuli decreases, while irritability and the appearance of negative feelings increase [37].

The spaces providing mental refreshment are described by R. and S. Kaplan with four primary characteristics: 1. a location that is both physically and mentally distant from the workstation; 2. a design different from the work environment, which helps to divert thoughts from the activity performed so far by new stimuli; 3 . proximity to nature or some refreshing environment [38]; 4. a design in line with the function of the space, compatibility.

Section 2 of the criteria of the ART justifies the different character of the design of the proposed lounges as compared to the work environment: the mixed-use of materials and colors in the spaces serves to distract the employees. The stimuli generated by the natural materials and warm colors used in the recreational areas inevitably distract the user, thus helping to reduce stress and recover faster.

Refreshing and natural environment (ART, section 3) can be created in the lounges by planting plants - e.g., phonebooth lounge, with the use of wooden coverings on a large surface e.g., e-sport lounge, as well as by using natural earth tones. The simple design and unadorned character of the areas are justified by section 4 of the theory: by avoiding unnecessary decorative elements and details, the number of stimuli diverting attention from regeneration is reduced.

The concept of the lounges was also based on the circumstances described in the first half of the study. The primary conceptual aspect was to respond to the issues of open-plan office design by creating informal spaces in where the visual, verbal, and physical privacy of the employees could be provided; also we strived to support the preservation of mental and physical health as much as possible through function and design (Figure 8).

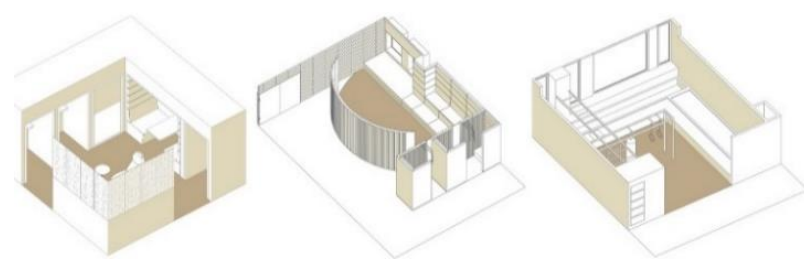

Figure 8. Conceptual axonometric drawings of the designed lounges

\subsection{External delimitation}

The partial or complete delimitation of the lounges from the traffic side has a dual role: the surfaces applied act as acoustic and visual delimiters. The goal is to create separate rooms that do not have a closed, 'room-like' feeling, but can be wholly separated from the adjacent spaces if required. The surfaces represent the underlying function, and accordingly, their design is adapted to the interior materials applied and the style of the lounges; but does not differ strikingly from the materials of the surrounding surfaces (Figure 9).

In the phonebooth lounge, we created furniture by extending the interface between the corridor and the lounge: the lower part of which is suitable for planting plants, while the upper part provides the acoustic and visual delimitation of the room. In order to provide enhanced functionality, the room is only partially closed, and the sound resulting from use is absorbed by the soundproofing plasterboard structures and the acoustic wall coverings. The paneled and perforated wood materials used on the interface differ from the materials applied in the work areas; still, they fit into the office environment.

The delimiting surfaces of the e-sport lounge are also made of wood: paneled on the side of the telephone booths, while interspaced wainscoting design was applied along the curve of the display. The room is partially open, but complete separation can be provided on request by retracting the soundproof curtains. To increase the effect of sound insulation and for aesthetic reasons, the acoustic wall covering of the lounge was applied on the connected surfaces as well.

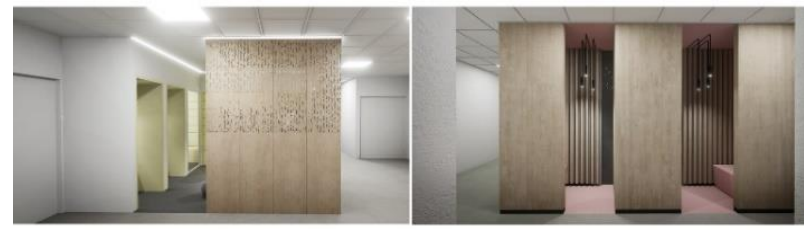

Figure 9. External delimitation of the designed lounges

The use of color in the interfaces of the sports lounge is the same as that used in the work areas of the office; its use was justified by the need for acoustic and visual separation. The hollow-chamber polycarbonate sheets used as a sliding surface fit well into the slightly industrial atmosphere of the room, and their partial transparency makes the underlying function mysteriously visible. Thanks to the gypsum plasterboard walls with increased sound insulation, noise from sports can be blocked. 


\subsection{The use of colors and materials in the lounges}

The need to deviate from the workspaces determined the color and material choice of lounges, just as functional considerations. Typical materials in office spaces: glass, metal, laminated furniture boards, upholstery of and seating furniture and screens; their use of color is mostly neutral. The coldness and cleanliness of materials and colors applied in the formal rooms were counterbalanced by the use of natural materials and warm colors in the informal areas. When choosing the colors used in the lounges, their specific, indirect psychological effect and impulse strength were taken into consideration $[39,40]$.

The central zone and cabin-like system of the phonebooth lounge use different materials and colors: paneled and perforated wood was applied for the boundaries and ceiling coverings in the central group area, while the external surfaces of the cabins are painted white and the internal acoustic cover is dull yellow. The yellow color of the sound-absorbing wall coverings has an energizing, communication and creativityenhancing effect [41], and its application on side, vertical surfaces has a warming and closing-up effect. The large white surfaces in the area radiate neutrality, serenity and purity [42]; besides they play an important role in neutralizing and separating brighter colors.

Functional needs justified the choice of material for the esport lounge: the pyramid-shaped sound-absorbing sponge cover covering the transverse walls and parts of the ceiling absorbs most of the noise generated in the space; also due to its special texture, it contributes to enhancing the atmosphere of the room. The black walls of the lounge contrast with the use of light colors in the rest of the office space - helping to distract the user quickly. The white ceiling and light floor give the feeling of a space with a higher ceiling height, while the black cladding of the walls has a closing-up, enveloping effect. The light rose shade used on the interior upholstery of the sofa, and the phonebooths has a soothing, relaxing effect. The warm-colored upholstery and natural wood surfaces used in the space provide a cosy atmosphere to the otherwise monochrome room.

When creating the concept for the sports lounge, practical considerations were given priority in terms of choosing materials and colors: the small room, illuminated from one side, was optically enlarged using bright colors and mirror surfaces. The white color used on the walls and some of the furniture, the light raw concrete surface of the ceiling, and the light grey upholstery of the floor create a feeling of lightness, cleanliness and tranquility. The wood paneling used in the lining of the shelving systems and on the seating surfaces counterbalances the slightly industrial atmosphere of the space. The raster of the low-division, black powder-sprayed grid system divides the surfaces and partially covers the HVAC appliances.

\subsection{Acoustic design of lounges}

A common problem with open-plan offices is the noisy work environment; more than $30 \%$ of those completing the employee questionnaire mentioned noise as a factor negatively affecting their work efficiency. By relocating some noisy activities - e.g., by small group meetings, private conversations, phone calls - the noise load of office area can be reduced. Increased sound insulation in informal spaces is intended to prevent the infiltration of noise from office spaces and the disturbance of noise coming from recreational spaces. Providing a verbal privacy for employees in lounges increase their sense of security and enhance their mood.

In the phonebooths of the phonebooth lounge, the amount of noise coming out was reduced by using soundproof covers and curved surfaces. When designing the curves of the surfaces, we took into account the direction of convection of the speech sound, which can be planned in case of normal use. Perforated wood panels applied to the external interfaces of the central area for group events increase the acoustic comfort of the space and reduce the decay time to an optimal value.

In the area for group event within the e-sport lounge, adequate sound insulation was provided by utilizing an arched boundary structure, sound-absorbing sponge cover and soundabsorbing curtains; while the design of the telephone booths is the same as that of the booths of the telephone booth lounge. Thanks to the unique surface design of the pyramid-shaped sound-absorbing sponge cover used as a wall and ceiling covering, it absorbs a significant part of the sound waves, forming a so-called self-absorbing system.

In the case of the sports lounge, it was particularly important to set up an appropriate sound insulation system to prevent the noise of regular use from getting out. The partitions delimiting the space are made of advanced soundproofed mounted drywall systems, while the sliding surfaces are made of hollow chamber polycarbonate sheets. The dampening of the noise from footsteps is solved by using sports-tatami mat laid on the floor surface.

\subsection{Lighting design considerations}

The lighting system of phonebooths consists of artificial light. To fit the required functioning and to ensure the space's clarity, we created a soft and private atmosphere, with two lighting layers. The first layer is recessed lighting for a diffuse overhead light to give the entire space illuminance and global visualization. At the same time, the second layer opted for light zoning to emphasize the luminance of the individual areas, creating the sensation of privacy.

Due to the small area of the second-floor lounge, we opted for cove light which is indirect luminaire system. This lighting controls the perception of the surface by illuminating the edge of the walls and giving the space a more spacious impression. For the seating area, we selected a pendant light to afford ample lighting and create a relaxing space for employees combined with a directed spot with angles diffusion of $60^{\circ}$ for tasks performance. The selection of the phonebooths' illumination aimed to give volume to the cabin and emphasis their texture for that the accent lighting was picked [43, 44].

The lounges with the other activities of relaxation and exercises, have east daylighting penetration plus overhead diffuse as artificial light. This last contributes to an overall luminance area with the avoidance of glare, the design of lighting topography and distribution is similar in these lounges but it differentiates in the level of lamps types and intensity according to the lounge's function. The purpose of the identification of light position and its distribution is to figure out the luminous flow within the space.

The general light atmosphere is principally related to the lighting level and the correlation color temperature emitted from the light source (CCT). According to many studies about the preference of lighting atmosphere, a low CCT or a warm temperature of light is perceived more preferable. We adopted warm light in all the lounge designs to enhance the satisfaction 
of workers and fit the adequate role of the lounges. The warm lighting is from $2700 \mathrm{k}$ to $3300 \mathrm{k}$, is opted for houses, and places needing domestic and private impression [44, 45].

The combination of a diffuse lighting and a low CCT contribute to the lounges' relaxed atmosphere and to emphasize the privacy of the focus lounges [43, 44].

Besides the CCT, the level of lighting is a primordial variable for the visual task and the atmosphere quality of lounges, according to the previous studies and our questionnaire done for workers' satisfaction of the company, the lighting level has a significant effect on user liking [46].

The main feature of the focus lounges design is to combine the functional and subjective lighting installations, meaning that each lighting layer has its individual brightness level: the overhead and cove lighting is a dim light with a brightness between 100 lux to 150 lux providing a lively atmosphere combined with the warm lighting. For individual seating and cabins, we keep the lighting illumination subjective by using dimmable lighting with a variety of 200 lux to 300 lux [45, 47].

The lighting of the sport and creative lounges that benefit of daylight penetration, is integrated to fit the outdoor illuminance. A Canadian study affirmed that the daylight source should be the primary light source for the well-being and health of users. On the other hand, the lighting level of space needs to be controlled according to the function of the lounge: in the case of the e-sport lounge, for example, the required lighting level should be dimmed to 50 lux in order to be comfortable for screen viewing $[45,47]$.

The lighting of the lounges is controlled partially manually in the focus area giving the employee the option of deciding the light quality according to their preferences. The light comfort and functional conditions influence the feeling of intimacy and improve the well-being of employees.

In the sports lounge, the smart lighting control helps to adapt the indoor lighting according to the daylight and afford an adequate atmosphere through the sensors, resulting in an excellent visual quality and well-being.

\section{CONCLUSION}

During the following stage of the research, after reviewing the designed and existing spaces through the use of VRmodels, another questionnaire survey will be conducted, the results of which will decide if further redesigns are necessary. The advantage of the applied design methodology is that problem-solving based planning has become possible with the knowledge of the exact needs and requirements of the employees. The answers given in the questionnaire predetermined some of the physical features of the designed spaces. The feeling of congestion and lack of private space in spaces open to frequented traffic can only be mitigated by adequate acoustic and visual separation. The designed lounges can help to reduce the noise load of open-plan offices. The planned spaces must provide more to support the tasks and activities to be performed than the original work environment - thus, the willingness to use them develops.

\section{ACKNOWLEDGMENT}

The research was conducted at the University of Pécs, Hungary, EU, within the framework of the Biomedical Engineering Project of the Thematic Excellence Programme
2019 (TUDFO/51757-1/2019-ITM)

\section{REFERENCES}

[1] Candido, C., Chakraborty, P., Tjondronegoro, D. (2019). The rise of office design in high-performance, open-plan $\begin{array}{lll}\text { environments. } & \text { Buildings, } & 9(4):\end{array}$ https://doi.org/10.3390/buildings9040100

[2] Kim, A., Wang, S., McCunn, L., Prozuments, A., Swanson, T. (2019). Commisioning the acoustical performance of an open office space following the latest healthy building standard: A case study. Acoustics, 1(3): 473-492. https://doi.org/10.3390/acoustics1030027

[3] Delle Macchie, S., Secchi, S., Cellai, G. (2018). Acoustic issues in open plan offices: A typological analysis. Buildings, $8(11)$ : https://doi.org/10.3390/buildings8110161

[4] Di Balsio, S., Shtrepi, L., Puglisi, G.E., Astolfi, A. (2019). A cross-sectional survey on the impact of irrelevant speech noise on annoyance, mental health and well-being, performance and occupants' behavior in shared and open-plan offices. International Journal of Environmental Research and Public Health, 16(2): 280. https://doi.org/10.3390/ijerph16020280

[5] Kim, D.H., Bluyssen, P.M. (2020). Clustering of office workers from the OFFICAIR study in The Netherlands based on their self-reported health and comfort. Building and Environment, 176: 106860. https://doi.org/10.1016/j.buildenv.2020.106860

[6] Alberdi, A., Aztiria, A., Basarab, A. (2016). Towards an automatic early stress recognition system for office environments based on multimodal measurements: A review. Journal of Biomedical Informatics, 59: 49-50. https://doi.org/10.1016/j.jbi.2015.11.007

[7] Szolnoki, B., Berényi, L. (2014). Az irodai munkavégzés ergonómiájának hatása a munka minőségére. Minőség És Megbízhatóság, 47(2): 99-100.

[8] Szolnoki, B., Berényi, L. (2016). A munkahelyi egészségfejlesztés szükségessége és lehetőségei. Gradus, 3(1): 495-500.

[9] Bluyssen, P.M., Roda, C., Mandin, C., Fossati, S., Carrer, P., de Kluizenaar, Y., Mihucz, V.G., Fernandes, E., Bartzis, J. (2016). Self-reported health and comfort in 'modern' office buildings: First results from the European OFFICAIR study. Indoor Air, 26(2): 298-300. https://doi.org/10.1111/ina.12196

[10] Lindquist, T.L., Cooper, C.L. (1999). Using lifestyle and coping to reduce job stress and improve health in 'at risk' office workers. Stress Medicine, 15(3): 144-146. https://doi.org/10.1002/(sici)1099-

1700(199907)15:3<143::aid-smi808>3.0.co;2-4

[11] Profession.hu Kft. (2019). Representative Survey.

[12] Survey of European Foundation for the Improvement of Living and Working Conditions (2015). European Working Conditions Survey.

[13] Danielsson, C. (2005). Office environment, health \& job satisfaction an explorative study of office design's influence. Licentiate Thesis, The Royal Institute of Technology, Stockholm, Sweden, pp. 1-2. ISBN: 917178-168-4. http://orcid.org/0000-0003-2432-7617

[14] Shafaghat, A., Keyvanfar, A., Lamit, H., Mousavi, S.A., Abd Majid, M.Z. (2014). Open plan office design features affecting staff's health and well-being status. 
Jurnal Teknologi, $\quad$ 70(7): $\quad$ 83-85 https://doi.org/10.11113/jt.v70.3583

[15] Taskin, L., Parmentier, M., Stinglhamber, F. (2019). The dark side of office designs: towards de-humanization. New Technology, Work and Employment, 34(3): 262264. https://doi.org/10.1111/ntwe.12150

[16] Duval, C.L., Charles, K.E., Veitch, J.A. (2002). Openplan office density and environmental satisfaction. NRC Publications Archive (NPArC)Archives des publications $\mathrm{du}$ CNRC (NPArC), pp. 4-12. https://doi.org/10.4224/20377537

[17] Banbury, S., Berry, D.C. (1998). Disruption of officerelated tasks by speech and office noise. British Journal of Psychology, 89(3): 499-500. https://doi.org/10.1111/j.2044-8295.1998.tb02699.x

[18] Ashkanasy, N.M., Ayoko, O.B., Jehn, K.A. (2014). Understanding the physical environment of work and employee behavior: An affective events perspective. Journal of Organizational Behavior, 35(8): 1169. https://doi.org/10.1002/job.1973

[19] Jahncke, H., Halin, N. (2012). Performance, fatigue and stress in open-plan offices: The effects of noise and restoration on hearing impaired and normal hearing individuals. Noise Health, 14: 260-272. https://doi.org/10.4103/1463-1741.102966

[20] Toftum, J., Lund, S., Kristiansen, J., Clausen, G. (2012). Effect of open-plan office noise on occupant comfort and performance. 10th International Conference on Healthy Buildings - Brisbane Convention \& Exhibition Centre, Brisbane, Australia, pp. 1-2.

[21] Vellenga-Persoon, S., Höngens, T. (2015). Acoustic measurements in retrofit buildings lead to a sustainable design of a (Semi-) open plan office. Energy Procedia, 78: https://doi.org/10.1016/j.egypro.2015.11.243

1641-1646.

[22] Charles, K.E., Veitch, J.A. (2002). Environmental satisfaction in open-plan environments: 2. effects of workstation size, partition height and windows. Institute for Research in Construction National Research Council Canada Montreal Road, Ottawa, Ontario, pp. 11-12. https://doi.org/10.4224/20378854

[23] Bodin Danielsson, C., Bodin, L. (2009). Difference in satisfaction with office environment among employees in different office types. Journal of Architectural and Planning Research, 26(3): 241-257.

[24] Marquardt, C.J.G., Veitch, J.A., Charles, K.E. (2002). Environmental satisfaction with open-plan office furniture design and layout. NRC Publications Archive (NPArC) Archives des publications du CNRC (NPArC). https://doi.org/10.4224/20378656

[25] Ilyés, Z. (2016). Informális munkaterek: Irodai és oktatási terek használatának lehetőségei. Építészet \& Oktatás: A BME Építőmüvészeti Doktori Iskola tanulmánykötete 2015/16, pp. 234-245.

[26] Berkup, S.B. (2014). Working with generations $X$ and $Y$ in generation $\mathrm{Z}$ period: Management of different generations in business life. Mediterranean Journal of Social Sciences, 5(9): 218-226. https://doi.org/10.5901/mjss.2014.v5n19p218

[27] Beekman, T. (2011). Fill in the Generation Gap. Strategic Finance, 15-16.

[28] Combes, B.A. (2009). Generation Y: Are they really digital natives or more like digital refugees? Synergy, 7(1): 31-32.
[29] Benckendorff, P., Moscardo, G. (2010). Tourism and Generation Y. First edition. CAB International. ISBN: 1845936027.

[30] Bernstein, L.E. (2006). Generations Working Together: What Everyone Needs to Know and Do! USA: Visionpoint Productions Inc., The Walk the Talk Company. ISBN: 1885228708.

[31] Szombathelyi, K.M. (2017). Munkahelyek, irodák, generációk és nemek: Hogyan alkalmazkodik a munkahelyek építészete a generációs és nemi elvárásokhoz? Társadalmi Nemek Tudománya Interdiszciplináris Efolyóirat, 7(1): 91-95.

[32] Rolfö, L.V. (2018). Relocation to an activity-based flexible office - Design processes and outcomes. Applied Ergonomics, 73: 144-145. https://doi.org/10.1016/j.apergo.2018.05.017

[33] Littlefield, D. (2019). Good Office Design. London: RIBA https://doi.org/10.4324/9780429347757

[34] Morrison, R.L., Smollan, R.K. (2020). Open plan office space? If you're going to do it, do it right: A fourteenmonth longitudinal case study. Applied Ergonomics, 82: 4-5. https://doi.org/10.1016/j.apergo.2019.102933

[35] Szolnoki, B., Berényi, L. (2016). A munkahelyi egészségfejlesztés szükségessége és lehetőségei. Gradus, 3(1): 495-500.

[36] Jahncke, H. (2011). Open-plan office noise: Cognitive performance and restoration. Journal of Environmental Psychology, 31(4): 373-382. https://doi.org/10.1016/j.jenvp.2011.07.002

[37] Sallay, V. (2008). Az önmagunkra találás helyei: környezeti önszabályozás elmélet és kutatás tükrében. Alkalmazott Pszichológia, 10(3-4): 149-150.

[38] Genjo, K., Matsumoto, H., Ogata, N., Nakano, T. (2019). Feasibility study on mental health-care effects of plant installations in office spaces. Japan Architectural Review, 2(3): 1-4. https://doi.org/10.1002/2475-8876.12098

[39] Neufert, E. (2002). Építés- és Tervezéstan Kézikönyv építészek, tervezők, beruházók, kivitelezők, oktatók és hallgatók számára. First hungarian ed. Budapest-Pécs: Dialóg Campus Kiadó. ISBN: 963-9123-31-5.

[40] Kwallek, N., Soon, K., Lewis, C.M. (2007). Work week productivity, visual complexity, and individual environmental sensitivity in three offices of different color interiors. Color Research \& Application, 32(2): 130-132. https://doi.org/10.1002/col.20298

[41] Kwallek, N., Lewis, C.M., Lin-Hsiao, J.W.D., Woodson, H. (1996). Effects of nine monochromatic office interior colors on clerical tasks and worker mood. Color Research \& Application, 21(6): 448-450. https://doi.org/10.1002/(sici)15206378(199612)21:6<448::aid-col7>3.0.co;2-w

[42] Öztürk, E., Y1lmazer, S., Ural, S.E. (2012). The effects of achromatic and chromatic color schemes on participants' task performance in and appraisals of an office environment. Color Research \& Application, 37(5): 362-365. https://doi.org/10.1002/col.20697

[43] Kofod, C. (2017). Indoor Lighting in the Public and Private Service Sectors. Guidelines for Indoor Lighting in the Public and Private Service Sector, 1-56.

[44] van Erp, T.A.M. (2008). The effects of lighting characteristics on atmosphere perception. Eindhoven University of Technology - Department of Technology Management Educational Program Technical Innovation 
Science Master's Program Human Technology Interaction.

[45] Salonen, H., Lahtinen, M., Lappalainen, S., Nevala, N., Knibbs, L.D., Morawska, L., Reijula, K. (2013). Physical characteristics of the indoor environment that affect health and wellbeing in healthcare facilities: A review. Intelligent Buildings International, 5(1): 3-25. https://doi.org/10.1080/17508975.2013.764838
[46] Odabaşioğlu, S., Olguntürk, N. (2015). Effects of coloured lighting on the perception of interior spaces. Perceptual and Motor Skills, 120(1): 183-201. https://doi.org/10.2466/24.pms.120v10x4

[47] Christoffersen, J. (2011). The importance of light to health and well-being. Conference: 4th VELUX Daylight Symposium "Daylight in a Human Perspective". 